\title{
CIRCULAR ECONOMY IN MATERIAL SELECTION: A SYSTEMATIC LITERATURE REVIEW
}

Mariana de Lourdes Rodrigues da Costa (marilro@hotmail.com.br) - Instituto Federal de Educação, Ciência e Tecnologia de Minas Gerais (IFMG).

Lucas Henrique Maria (lucasm2796@gmail.com) - Instituto Federal de Educação, Ciência e Tecnologia de Minas Gerais (IFMG).

Camila Gonçalves Castro (camilagcastro@usp.br) - Instituto Federal de Educação, Ciência e Tecnologia de Minas Gerais (IFMG).

Renata Veloso Santos Policarpo (renataveloso@ifmg.edu.br) - Instituto Federal de Educação, Ciência e Tecnologia de Minas Gerais (IFMG).

\begin{abstract}
One of the issues in the area of sustainability concerns circular economy (CE), which consists of the conscious use of concentrated resources, the reduction of waste generation, and the minimum use of primary resources. In this sense, one of the areas affected by the $\mathrm{CE}$ is product development, notably in the material selection process, which is currently being designed taking into account $\mathrm{CE}$ processes, such as recycling, reuse, and remanufacturing. Therefore, to map the methods of material selection used in the product development process while also identifying the adopted principles of the $\mathrm{CE}$, this article develops a systematic review of the literature. The results point to an approach that utilizes CE-related concepts, in special recycling and energy, the two most prevalent concepts, as criteria for using material selection tools.
\end{abstract}

Keywords: product design; circular economy; material selection; sustainability 


\section{INTRODUCTION}

One of the issues in the area of sustainability concerns the circular economy (CE). According to Bovea and Pérez-Belis (2018), there has been a growing trend in recent years for the development and conceptualization of CE models. Morseletto (2020) defines CE as a model directed at the efficient use of specialized resources, aiming at minimizing waste, reducing primary resources, and having closed-loop production processes and material cycles within the limits of environmental protection.

For He et al. (2020), reducing the impact on the manufacturing process is seen as one of the best practices to reach sustainability. The concept of sustainability for a product or process is related to restricting the consumption of resources and the generation of waste to an acceptable level. It requires positive contributions that satisfy human needs and provide sustainable economic values for companies (Bakshi \& Fiksel, 2003; Genç et al., 2015).

In this context, a $\mathrm{CE}$ interferes with the material selection process, since, according to De Schoenmakere and Gillabel (2017), the use of circular materials has the potential to bring economic and environmental benefits, being increasingly recognized as the mechanism for using resources that will enable social-ecological sustainability.

One of the areas where sustainability and CE interfere more directly is in the product development process, which is described as the process that comprises the initial recognition of a market opportunity plus technical strategies and capacities of the production, sale, and delivery of a product until its discontinuity (Pessôa \& Trabasso, 2017).

In their studies, Liu and Bai (2014) show a gap concerning CE in companies, as it is not part of their cultural behavior. The authors mention there is no eagerness to adopt the principles of $\mathrm{CE}$, indicating that it is not a matter of increasing knowledge. The $\mathrm{CE}$ as a subject has limited itself to references to existing research areas, such as projects for recycling, disassembly, and remanufacturing (Van Den Berg \& And Bakker, 2015).

Given this, concepts related to the CE still do not have enough tools to assist in product development, especially in relation to the material selection process, which, as shown in the literature, is limited to indirectly employing the concepts related to this theme.

For instance, there are different frameworks related to the CE, including extending the life cycle of resources, reducing, reusing, recycling, remanufacturing, maintenance, repair, transforming waste into energy, and increase product longevity (Blomsman and Brennan, 2017). These frameworks, however, lack specific tools for the material selection process. The present study is based on exploring the following question: 
- How are CE actions included in the methods for selecting materials in product development? Based on this issue, the objectives consist of:

- Mapping the methods and tools for selecting materials used in the product development process;

- Identifying which CE principles are most effective in selecting materials.

The present study is justified by the importance of material selection in the design of a product and also by the relevance of strategies adopted to close and slow down the resource cycle, as shown by Vogtländer et al. (2014). To explore this unresolved issue, a systematic review of the literature has been done.

\section{THEORETICAL REVIEW}

\subsection{Circular Economy}

The $\mathrm{CE}$ is a regenerative system in which the emission and leakage of energy and the entry and waste of resources are minimized, whether by the deceleration, closure, or narrowing of material and energy loops (Geissdoerfer et al., 2017). CE can be achieved through repair, reuse, remanufacturing, and long-term recycling (Geissdoerfer et al., 2017; Mesa et al., 2018). According to Reike et al. (2018), the process of reduction means buying products less often and being mindful of their use so they have greater durability. In relation to designers, there should be some concern about the use of less material per production unit.

MacArthur (2020) reports that the reuse process involves the use of a product again for the same purpose with few changes or improvements, or even in its original form. Recycling, however, is the process of recovering materials for their original purpose or other purposes. According to these authors, remanufacturing is defined as a disassembly and recovery process at the component or subassembly level, the reusable and functional parts being removed from a used product and rebuilt into a new one.

This process guarantees the quality of the component and of any potential changes or improvements. One of the strategies towards CE concerns products having durability, extending their life cycle as in the study by Kalmykova et al. (2018) that used modularity as a strategy. Products with functional modules accept being updated with other resources or new functionalities. These modules can be replaced or repaired, thus increasing the longevity of the product. 


\subsection{Product development}

The development of sustainable products refers to a strategic concept of sustainability that is consolidated and carried out in the initial phases of the product innovation process, including its life cycle (Hallstedt \& Isaksson, 2017). Rozenfeld et al. (2006) divide product development into three macro phases and then into smaller stages, which are:

- Pre-development, which involves strategic product and project planning;

- Development, with the stages of informational design, conceptual design, detailed design, preparation of product production, and product launch;

- Post-development, whose phases consist of monitoring and improving the product and discontinuing it.

Given the importance of each phase in product development and the necessary information (Cui et al., 2014), the initial stage requires attention, given the amount of knowledge it involves. The initial development can influence the degree to which information is understood and the developers' experience can interfere with whether the product design will be successful or not.

It is essential to understand the criticality of materials from a complete perspectiveeconomically, environmentally, and socially_so decisions are made in the phases when materials are selected, that is, in the first phases of product development (Hallstedt \& Isaksson, 2017).

\subsection{Material selection}

Material selection procedures depend on several types of criteria, such as dimensional considerations, knowledge of variables of operation, mechanical strength, durability requirements, among others. In this sense, the material is selected from a set of conflicting parameters that must be found concurrently. Material selection tools must consider functions and suggest proposals for different but equally satisfactory alternatives (Ferrante, 2002).

In the material selection process, the problem consists of identifying the desired attribute and comparing to other materials to find a better combination. The material selection strategy consists of four fundamental steps (Ashby et al. (2004):

- Translation of design requirements into parameters, which identifies the restrictions that must be met and the desired objective;

- Exclusion of all materials that do not meet the restrictions; 
- Classification of materials that remain on the list by the fulfillment of its objective;

- Documentation of the best-ranked candidates to analyze them more deeply.

In the material selection process, a series of variables are considered in decision making (Karande \& Chakraborty, 2012). In this context, according to (Jahan et al., 2011), multicriteria decision-making methods such as AHP, VIKOR, and TOPSIS can help designers choose the best material to meet their needs.

\section{MATERIALS AND METHODS}

Systematic reviews (SR) aim at reducing the influence of subjectivity. The best and most useful ones utilize selected and revised literature to evaluate an existing theory or even to create a new one (Siddaway et al., 2019). In this sense, SR are a type of research that follows specific steps and seeks to understand and logically explain a large documentary corpus (Galvão \& Ricarte, 2019).

\subsection{Article selection process}

To accomplish the proposed SR, it was necessary to choose databases with a large volume of journals on the most diverse subjects, including the theme of this work. As such, Scopus and Web of Science were chosen, as they meet this requirement. The article selection process was divided into four stages: selection by title, abstract, methodology, and complete reading.

Initially, the articles were selected through the titles available in the chosen databases between 2010 and 2020. For that, some keywords were chosen because of their relation to material selection and product development. Chart 1 presents these keywords, and inclusion and exclusion items of this stage. During the selection by summary, items were deemed inclusion items if related to product development or material selection and exclusion items in the absence of such content.

The next step was to select the materials and methods used in the articles with the objective of distributing them among the following categories: presents a case study, proposes or evaluates material selection, or develops a product. The selected items proposed a material selection methodology and presented a case study; those that did not fit were excluded.

The last step was to select the articles via their complete reading, accepting studies that present material selection methods in the product development process and excluding those that did not fit such requirements. To illustrate the steps mentioned above, a flowchart was 
created, Figure 1. The first step returned 14,766 articles; after completing the remaining steps, 20 papers met all the criteria.

CHART 1 - Criteria used in the first stage of analysis.

\begin{tabular}{|c|c|c|}
\hline Keywords & Inchusion items & Exchusion items \\
\hline $\begin{array}{l}\text { Development sustainable new } \\
\text { products }\end{array}$ & $\begin{array}{l}\text { Complete and conchided } \\
\text { papers and conference } \\
\text { papers }\end{array}$ & $\begin{array}{l}\text { Literature review, } \\
\text { monographs }\end{array}$ \\
\hline $\begin{array}{l}\text { Development new materials } \\
\text { sustainable }\end{array}$ & $\begin{array}{l}\text { Publications in the years } \\
2010-2020\end{array}$ & $\begin{array}{l}\text { Diss ertations, theses, and } \\
\text { editorials }\end{array}$ \\
\hline $\begin{array}{l}\text { Products developments with } \\
\text { materials sustainable }\end{array}$ & $\begin{array}{l}\text { Publication pres ent in the } \\
\text { sub-areas: Engineering; } \\
\text { Environmental Science; } \\
\text { Materials Science; Energy; } \\
\text { Business, Management and } \\
\text { Accounting; Computer } \\
\text { Science; Science }\end{array}$ & $\begin{array}{l}\text { Articles presents in the sub- } \\
\text { area: medicine }\end{array}$ \\
\hline
\end{tabular}

From the reading of the complete papers and the elaborated codifications, a matrix was drawn considering the methods adopted for material selection and the parameters of the CE, such as reuse, remanufacture, recycling, reduction, energy, and life cycle. 


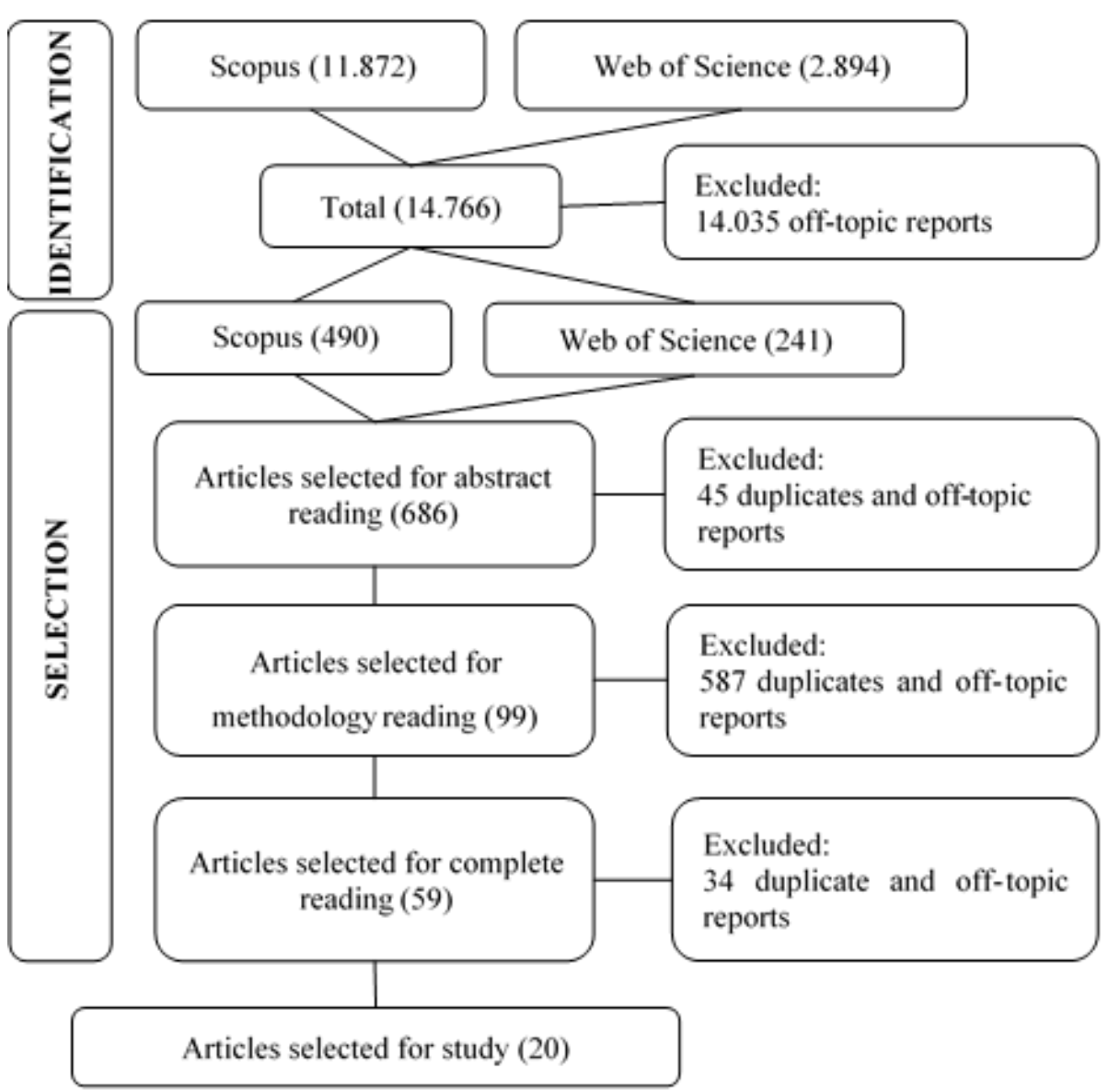

FIGURE 1 - Flowchart of methodological processes.

\section{RESULTS AND DISCUSSIONS}

Table 1 describes the 20 articles selected. The studies were codified and listed by authors and by year, also containing the products analyzed in each one. As noted in Table 2, the studies were classified according to material selection tools/methods identified during reading based on the principles of the $\mathrm{CE}$ adopted as criteria in the articles.

TABLE 1 - Selected articles. 


\begin{tabular}{|c|c|c|}
\hline Number & Authors & Studied product \\
\hline [1] & (Djas semi, 2012) & Lawnmower eng ine cy linder block \\
\hline [2] & (Zhao et al., 2016) & Plast ic tube \\
\hline [3] & (Shaharuzaman et al, 2019) & Automotive side impact beam \\
\hline [4] & (Dos Santos et al, 2016) & $\begin{array}{l}\text { Structural components for trucks, such as } \\
\text { suspension brackets }\end{array}$ \\
\hline$[5]$ & (Mesa et al, 2020) & Finger pros thet ic device \\
\hline [6] & (Manjunatheshwara \& Vinodh, 2018) & Tablet compartment \\
\hline [7] & (Mans or et al., 2013) & $\begin{array}{l}\text { Pas senger car central lever parking brake } \\
\text { components }\end{array}$ \\
\hline [8] & (García-Gil et al., 2020) & Process of solar disinfection of water \\
\hline [9] & (Prendeville et al, 2014) & $\begin{array}{c}\text { Cases A, B, and C: work chair; } \\
\text { Case D: visitor chair }\end{array}$ \\
\hline$[10]$ & (Dos Santos et al, 2016) & Aeronautical fumiture structural panels \\
\hline$[11]$ & (Ferro \& Bonollo, 2019) & $\begin{array}{c}\text { Bicycle forks } \\
\text { Connecting rod forhigh-performance } \\
\text { engines }\end{array}$ \\
\hline$[12]$ & (Zarandi et al, 2011) & Tire \\
\hline [13] & (Tambouratzis et al, 2014) & Liquid container \\
\hline$[14]$ & (Yang et al., 2017) & Engine block and intake manifold \\
\hline$[15]$ & (Pagone et al, 2020) & Automotive components \\
\hline$[16]$ & (Bakhoum \& Brown, 2015) & Structural construction materials \\
\hline$[17]$ & (Mayyas et al., 2016) & Car body panels \\
\hline$[18]$ & (A. T. Mayyas \& Omar, 2012) & Body of a passage vehicle \\
\hline$[19]$ & (Hallstedt \& Isaksson, 2017) & Components used for aircraft \\
\hline$[20]$ & (Ghose et al., 2019) & Solar electric vehicle \\
\hline
\end{tabular}

In the results, it is seen that the tools support CE actions, adopting their approaches as a criterion in the stages of material selection. As such, the most addressed topic was recycling, and the second was energy; for instance, energy used to produce the product or the material. The methods that stood out in the approaches were the new ones, AHP and QFD.

Third is the life cycle analysis approach, in which the new ones, the AHP, QFD, and LCA, stood out as the best-known methods. Another point to be highlighted is that the remanufacturing criterion is used in only a few studies that involve material selection processes, more specifically in those that deal with component disassembly and reconstruction.

TABLE 2 - Results. 


\begin{tabular}{|c|c|c|c|c|c|c|}
\hline $\begin{array}{l}\text { Tools/Methods of } \\
\text { material selection }\end{array}$ & Reduce & Reuse & Recycle & Remanufacturing & Life cycle & Energy \\
\hline $\begin{array}{l}\text { Analytic Hierarchy } \\
\text { Process (AHP) }\end{array}$ & {$[2,17]$} & {$[2,3,7]$} & $\begin{array}{r}{[2,3,7} \\
17,18]\end{array}$ & & [18] & $\begin{array}{r}{[2,3,7} \\
17,18]\end{array}$ \\
\hline $\begin{array}{l}\text { Artificial neural networks } \\
\text { (ANNs) }\end{array}$ & & & [13] & & [13] & [13] \\
\hline $\begin{array}{l}\text { Critical Raw Materials } \\
\text { (CRMs) }\end{array}$ & & & [11] & & & \\
\hline Fuzzy Complex & & & & & & \\
\hline $\begin{array}{l}\text { Proportional Assessment } \\
\text { (COPRAS) }\end{array}$ & & & [20] & & & [20] \\
\hline $\begin{array}{l}\text { Fuzzy Technique of } \\
\text { ranking Preferences by } \\
\text { Similarity to the Ideal } \\
\text { Solution (Fuzzy TOPSIS) }\end{array}$ & {$[14,17]$} & [14] & {$[14,17]$} & [14] & [14] & {$[17]$} \\
\hline $\begin{array}{l}\text { Grey-based decision- } \\
\text { making model } \\
(\text { GBDMM) }\end{array}$ & & & [6] & & & [6] \\
\hline General regression (GR) & & & [13] & & [13] & [13] \\
\hline $\begin{array}{l}\text { Grey relational analysis } \\
\text { (GRA) }\end{array}$ & [2] & [2] & [2] & & & [2] \\
\hline $\begin{array}{l}\text { Life Cycle Assessment } \\
\text { (LCA) }\end{array}$ & & & {$[13,18]$} & & {$[13,15,18]$} & {$[13,15,18]$} \\
\hline $\begin{array}{l}\text { Material durability } \\
\text { indicator (MDI) }\end{array}$ & & & [5] & & & [5] \\
\hline $\begin{array}{l}\text { Multi-Criteria Decision } \\
\text { Analysis (MCDA) }\end{array}$ & & & & & [15] & [15] \\
\hline $\begin{array}{l}\text { Multi-Criteria Decision } \\
\text { Making (MCDM) }\end{array}$ & [14] & [14] & [14] & [14] & [14] & \\
\hline $\begin{array}{l}\text { Principal component } \\
\text { analysis (PCA) }\end{array}$ & [17] & & [17] & & & {$[17]$} \\
\hline $\begin{array}{l}\text { Preference selection } \\
\text { index (PSI) }\end{array}$ & [17] & & [17] & & & [17] \\
\hline $\begin{array}{l}\text { Quality Function } \\
\text { Deployment (QFD) }\end{array}$ & [17] & [10] & {$[10,17,18]$} & [10] & {$[10,18]$} & {$[10,17,18]$} \\
\hline $\begin{array}{l}\text { Technique for Order of } \\
\text { Preference by Similarity } \\
\text { to Ideal Solution } \\
\text { (TOPSIS) }\end{array}$ & [17] & & [17] & & [15] & {$[17,15]$} \\
\hline $\begin{array}{l}\text { VIseKriterijumska } \\
\text { Optimizacija I } \\
\text { Kompromisno Resenje } \\
\text { (VIKOR) }\end{array}$ & & [3] & [3] & & & [3] \\
\hline New methods & {$[10,19]$} & {$[9,10]$} & $\begin{array}{r}{[1,8,9,10} \\
12,16,19] \\
\end{array}$ & {$[10,19]$} & $\begin{array}{c}{[1,9,10} \\
12,16,19]\end{array}$ & $\begin{array}{l}{[1,4,8,9} \\
10,12,16]\end{array}$ \\
\hline
\end{tabular}

In the case of the studies selected in this review (Dos Santos et al., 2016; Hallstedt \& Isaksson, 2017; Yang et al., 2017), the remanufacturing criterion is used on studies of structural panels for aeronautical furniture, of engine blocks and intake manifolds, and on studies of components used on aircrafts, which demonstrates the applicability of this criterion 
in products that feature a set of components. These articles used the new methods and the Fuzzy-TOPSIS and MCDM methodologies, respectively.

Many studies have opted for the creation of new tools and methods for the selection of materials. Some studies (Dos Santos et al., 2016; García-Gil et al., 2020), presented new methods to meet the specific needs of the products developed in each study.

In case Prendeville et al. (2014), the material selection process needs to reflect the sector's behavior, legislation, trade-offs, access to knowledge, networks, and stakeholders. As such, that study presents SPICE, a new conceptual model that connects stakeholders, material selection, sustainable development, and trade-offs to assist in strategic project management and material selection for ecological innovations.

In work Zarandi et al. (2011), cited as justification for creating a new tool the fact that the selection of materials through life cycle engineering has a high cost; therefore, a new method has been developed, one that takes into account the knowledge of specialists on sustainable development.

Dos Santos et al. (2016) claim that no established procedures can help product designers reassess their previous designs and assist in making design decisions. As a result, they proposed a new method to select and change the materials used for vehicle components, one that is useful to alert and assist designers in updating their pre-existing designs.

For Djassemi (2012), eco-sustainability factors in product development may require manipulating enormous data and executing numerous calculations. The difficulty in incorporating quantitative data in evaluating the life cycle of a product is evident. Given this, the study presents a practical computer-aided procedure capable of assisting designers in the material selection process, one that incorporates environmental considerations in the analysis of a product's life cycle.

Studies have used more than one tool in the selection of materials. According to Mayyas et al. (2016) using more than one method is justified by their inclusion of several attributes in decision making. As each has its pros and cons, the comparison would ensure an efficient decision-making process when selecting the product's material. Ghose et al. (2019), used two methods to help designers integrate customer needs into the product.

\section{CONCLUSION}

The present study sought to answer the following research question: How are CE actions inserted in the methods for selecting materials in product development? Through a SR of the 
literature, we identified the most frequently used tools in the studies, namely AHP, QFD, LCA, and new ones that were developed in the papers.

One of the features of the AHP that justifies its use by developers of products is that it can be characterized as a tree, containing levels and sections. In which in the top section they can define and add the objectives or goals of the product, and in the second level can correspond the factors or criteria that interfere with the goals (Mansor et al., 2013). The RFD provides space to relate engineering parameters and customer needs through scores and weights for each (Mayyas et al., 2011).

The integration of the $\mathrm{CE}$ in material selection took place in the studies by adopting $\mathrm{CE}$ approaches as a criterion in the used tools. Although means to achieve sustainability have gained attention over the years, $\mathrm{CE}$ approaches show a difference in their integration in studies, with recycling and energy being more prominent in this research.

This study will contribute to designers and other professionals in the area, as materials selection has a primordial relevance to the CE strategy chosen for product development. The study contributes to the CE literature, as it advances it by offering more support for the development of products that fit the CE models. Its limitation was the quantity and quality of published studies on material selection in product development.

We can see the need for CE studies to address the tools for selecting materials for new products and not just reduced use strategies. Dematerialization is still a long-range objective, and material selection can strongly support other EC strategies. It can be seen in the research that the material selection tools focus on some CE strategies implicitly, addressing sustainability as a whole.

We emphasize how the selection of materials favors the CE and, through this study, other researchers can further direct design studies, contemplating how these tools help on the transition to the CE. This study helps other researchers and policymaker's direct strategies to facilitate the transition to the $\mathrm{CE}$, not only to indicate material selection practices that are more sustainable but also to verify which methods are more consistent with the principles of the CE.

\section{ACKNOWLEDGMENTS}

The authors gratefully thank Instituto Federal de Educação, Ciência e Tecnologia de Minas Gerais campus Congonhas for financial support with two grants and for support in the research. 


\section{REFERÊNCIAS}

Ameli, M., Mansour, S., \& Ahmadi-Javid, A. (2017). A sustainable method for optimizing product design with trade-off between life cycle cost and environmental impact. Environment, Development and Sustainability, 19(6), 2443-2456. https://doi.org/10.1007/s10668-016-9864-x

Ashby, M. F. (1999). Materials Selection in Mechanical Design. 2a ed., 665.

Ashby, M. F., Bréchet, Y. J. M., Cebon, D., \& Salvo, L. (2004). Selection strategies for materials and processes. Mater Des, 25, 51-67. https://doi.org/10.1002/1527-2648(20020605)4:6<327::AID-ADEM327>3.0.CO;2-N

Bakhoum, E. S., \& Brown, D. C. (2015). An automated decision support system for sustainable selection of structural materials. International Journal of Sustainable Engineering, 8(2), 80-92. https://doi.org/10.1080/19397038.2014.906513

Bakshi, B. R., \& Fiksel, J. (2003). The quest for sustainability: Challenges for process systems engineering. AIChE Journal, 49 (6), 1350-1358. John Wiley \& Sons, Ltd. https://doi.org/10.1002/aic.690490602

Blomsman, F., \& Brennan, G. (2017). The emergency of CE: A New Framing Around Prolonging Resource Productivity. The Journal of Industrial Ecology, 21, 603-614. https://doi.org/10.1111/jiec.12603

Bovea, M. D., \& Pérez-Belis, V. (2018). Identifying design guidelines to meet the CE principles: A case study on electric and electronic equipment. Journal of Environmental Management, 228, 483-494. https://doi.org/10.1016/j.jenvman.2018.08.014

Cui, A. S., Chan, K., \& Calantone, R. (2014). The learning zone in new product development. IEEE Transactions on Engineering Management, 61(4), 690-701. https://doi.org/10.1109/TEM.2014.2331757

De Schoenmakere, M., \& Gillabel, J. (2017) Circular by design-Products in the CE. European Environmenty Agency, 6. https://doi.org/10.2800/860754

Djassemi, M. (2012). A computer-aided approach to material selection and environmental auditing. Journal of Manufacturing Technology Management, 23(6), 704-716. https://doi.org/10.1108/17410381211253290

Dos Santos, C. V., Leiva, D. R., Costa, F. R., \& Gregolin, J. A. R. (2016). Materials Selection for Sustainable Executive Aircraft Interiors. Materials Research, 19(2), 339-352. https://doi.org/10.1590/1980-5373-MR-2015$\underline{0290}$

Ferrante, M. (2002). Seleção de Materiais. Editora da Univesidade Federal de São Carlo, 2, 286.

Ferro, P., \& Bonollo, F. (2019). Materials selection in a critical raw materials perspective. Materials and Design, 177. https://doi.org/10.1016/j.matdes.2019.107848

Galvão, M. C. B., \& Ricarte, I. L. M. (2019). Revisão sistemática da literatura: conceituação, produção e publicação. Logeion: Filosofia da Informação, 6(1), 57-73. https://doi.org/10.21728/logeion.2019v6n1.p57-73

García-Gil, Á., Pablos, C., García-Muñoz, R. A., McGuigan, K. G., \& Marugán, J. (2020). Material selection and prediction of solar irradiance in plastic devices for application of solar water disinfection (SODIS) to inactivate viruses, bacteria and protozoa. Science of the Total Environment, 730. https://doi.org/10.1016/j.scitotenv.2020.139126

Geissdoerfer, M., Savaget, P., Bocken, N. M. P., \& Hultink, E. J. (2017). The CE - A new sustainability paradigm?. Journal of Cleaner Production, 143, 757-768. https://doi.org/10.1016/j.jclepro.2016.12.048

Genç, E., Anthony, C., \& Benedetto, D. (2015). Cross-functional integration in the sustainable new product development process: The role of the environmental specialist. https://doi.org/10.1016/j.indmarman.2015.05.001

Ghose, D., Pradhan, S., Tamuli, P., \& Shabbiruddin. (2019). Optimal material for solar electric vehicle application using an integrated Fuzzy-COPRAS model. Energy Sources, Part A: Recovery, Utilization and Environmental Effects. https://doi.org/10.1080/15567036.2019.1668879

Hallstedt, S. I., \& Isaksson, O. (2017). Material criticality assessment in early phases of sustainable product development. Journal of Cleaner Production, 161, 40-52. https://doi.org/10.1016/j.jclepro.2017.05.085

He, B., Li, F., Cao, X., \& Li, T. (2020). Product Sustainable Design: A Review from the Environmental, Economic, and Social Aspects. Journal of Computing and Information Science in Engineering, 20 (4). https://doi.org/10.1115/1.4045408 
Jahan, A., Mustapha, F., Ismail, M. Y., Sapuan, S. M., \& Bahraminasab, M. (2011). A comprehensive VIKOR method for material selection. Materials and Design, 32(3), 1215-1221. https://doi.org/10.1016/j.matdes.2010.10.015

Kalmykova, Y., Sadagopan, M., \& Rosado, L. (2018). CE - From review of theories and practices to development of implementation tools. Resources, Conservation and Recycling, 135, 190-201. https://doi.org/10.1016/j.resconrec.2017.10.034

Karande, P., \& Chakraborty, S. (2012). Application of multi-objective optimization on the basis of ratio analysis (MOORA) method for materials selection. Materials and Design, 37, 317-324. https://doi.org/10.1016/j.matdes.2012.01.013

Liu, Y., \& Bai, Y. (2014). An exploration of firms' awareness and behavior of developing CE: An empirical research in China. Resources, Conservation and Recycling, 87, $145-152$. https://doi.org/10.1016/j.resconrec.2014.04.002

Lockrey, S. (2015). A review of life cycle based ecological marketing strategy for new product development in the organizational environment. Journal of Cleaner Production, 95, 1-15. Elsevier Ltd. https://doi.org/10.1016/i.jclepro.2015.02.022

Macarthur, E. (Org.). (2020). Towards the CE - Economic and Business Rationale for an Accelerated transition. Ellen Macarthur Found Rethink Futur, 100.

Manjunatheshwara, K. J., \& Vinodh, S. (2018). Grey-based decision-making method for sustainable material selection of tablet device enclosure. Clean Technologies and Environmental Policy, 20(10), 2345-2356. https://doi.org/10.1007/s10098-018-1610-7

Mansor, M. R., Sapuan, S. M., Zainudin, E. S., Nuraini, A. A., \& Hambali, A. (2013). Hybrid natural and glass fibers reinforced polymer composites material selection using Analytical Hierarchy Process for automotive brake lever design. Materials and Design, 51, 484-492. https://doi.org/10.1016/j.matdes.2013.04.072

Mayyas, A. T., \& Omar, M. A. (2012). Eco-material selection assisted with decision-making tools, guided by product's attributes; Functionality and manufacturability. International Journal of Materials and Structural Integrity, 6(2-4), 190-219. https://doi.org/10.1504/IJMSI.2012.049955

Mayyas, A., Omar, M. A., \& Hayajneh, M. T. (2016). Eco-material selection using fuzzy TOPSIS method. $\begin{array}{lllll}\text { International of Journal Sustainable } & \text { Engineering, } & 9(5), & 292-304 .\end{array}$ https://doi.org/10.1080/19397038.2016.1153168

Mayyas, A., Shen, Q., Mayyas, A., Shan, D., Qattawi, A., \& Omar, M. (2011). Using quality function deployment and analytical hierarchy process for material selection of body-in-white. Materials \& Design, 32(5), 2771-2782. https://doi.org/10.1016/i.matdes.2011.01.001

Mesa, J., Esparragoza, I., \& Maury, H. (2018). Developing a set of sustainability indicators for product families based on the CE model. Journal of Cleaner Production, 196, 1429-1442. https://doi.org/10.1016/j.jclepro.2018.06.131

Mesa, J., González-Quiroga, A., \& Maury, H. (2020). Developing an indicator for material selection based on durability and environmental footprint: A CE perspective. Resources, Conservation and Recycling, 160. https://doi.org/10.1016/j.resconrec.2020.104887

Morseletto, P. (2020). Targets for a CE. Resources, Conservation and Recycling, 153, 104553. https://doi.org/10.1016/j.resconrec.2019.104553

Pagone, E., Salonitis, K., \& Jolly, M. (2020). Automatically weighted high-resolution mapping of multi-criteria decision analysis for sustainable manufacturing systems. Journal of Cleaner Production, 257. https://doi.org/10.1016/j.jclepro.2020.120272

Pessôa, M. V. P., \& Trabasso, L. G. (2017). The Product Development System. The Lean Product Design and Development Journey. Springer International Publishing, 3-18. https://doi.org/10.1007/978-3-319-46792-4_1

Prendeville, S., O’Connor, F., \& Palmer, L. (2014). Material selection for eco-innovation: SPICE model. Journal of Cleaner Production, 85, 31-40. https://doi.org/10.1016/j.jclepro.2014.05.023

Reike, D., Vermeulen, W. J. V., \& Witjes, S. (2018). The CE: New or Refurbished as CE 3.0? — Exploring Controversies in the Conceptualization of the CE through a Focus on History and Resource Value Retention Options. Resources, Conservation and Recycling, 135, 246-264. https://doi.org/10.1016/j.resconrec.2017.08.027 
Rozenfeld, H., Forcellini, F. A., Amaral, D. P., Toledo, J. C. D., Silva, S. L. D., Alliprandini, D. H., \& Scalice, R. K. (2006). Desenvolvimento de Produto: Uma referência para melhoria do processo. Editora Saraiva.

Santos, J., Gouveia, R.M., \& Silva, F.J.G. (2017). Designing a new sustainable approach to the change for lightweight materials in structural components used in truck industry. Journal of Clean Production, 164, 115-23. https://doi.org/10.1016/j.jclepro.2017.06.174

Shaharuzaman, M. A., Sapuan, S. M., Mansor, M. R., \& Zuhri, M. Y. M. (2019). Decision support strategy in selecting natural fiber materials for automotive side-door impact beam composites. Journal of Renewable Materials, 7(10), 997-1010. https://doi.org/10.32604/jrm.2019.07529

Siddaway, A. P., Wood, A. M., \& Hedges, L. V. (2019). How to Do a Systematic Review: A Best Practice Guide for Conducting and Reporting Narrative Reviews, Meta-Analyses, and Meta-Syntheses. In Annual Review of Psychology (Vol. 70, p. 747-770). Annual Reviews Inc. https://doi.org/10.1146/annurev-psych-010418-102803

Tambouratzis, T., Karalekas, D., \& Moustakas, N. (2014). A methodological study for optimizing material selection in sustainable product design. Journal of Industrial Ecology, 18(4), 508-516. https://doi.org/10.1111/jiec.12035

Van Den Berg, M. R., \& And Bakker, C. A. (2015). A product design framework for a CE. In Proceedings of the PLATE Conference, Nottingham, UK, 17-19 June 2015 (Vol. 17). Nottingham Trent University: CADBE.

Vogtländer, J. G., Mestre, A., Helm, R. V. D., Scheepens, A., \& Wever, R. (2014). Eco-efficient Value Creation, sustainable strategies for the CE. Delft Academic Press.

Yang, S. S., Nasr, N., Ong, S. K., \& Nee, A. Y. C. (2017). Designing automotive products for remanufacturing from material selection perspective. Journal of Cleaner Production, 153, 570-579. https://doi.org/10.1016/j.jclepro.2015.08.121

Zarandi, M. H. F., Mansour, S., Hosseinijou, S. A., \& Avazbeigi, M. (2011). A material selection methodology and expert system for sustainable product design. International Journal of Advanced Manufacturing Technology, 57(9-12), 885-903. https://doi.org/10.1007/s00170-011-3362-y

Zhao, R., Su, H., Chen, X., \& Yu, Y. (2016). Commercially available materials selection in sustainable design: An integrated multi-attribute decision making approach. Sustainability (Switzerland), 8(1), 1-15. https://doi.org/10.3390/su8010079 